\title{
Effect of Plyometric Tuck Jumps and Lateral Hurdle Jumps on the Ability of Takraw Male Athletes to Do Smash Kedeng
}

\author{
$1^{\text {st }}$ Sulaiman \\ Departement Physical Education Sport, \\ Health and Recreation \\ Faculty of Sport Science Semarang State \\ University \\ Semarang, indonesia \\ sulaiman@mail.unnes.ac.id
}

\author{
$2^{\text {nd }}$ Agus Raharjo \\ Departement Physical Education Sport, \\ Health and Recreation \\ Faculty of Sport Science Semarang State \\ University \\ Semarang, indonesia \\ agusraharjo@mail.unnes.ac.id
}

\author{
$3^{\text {rd }}$ Wahyu Zaenal Abidin \\ Departemen Physical Education Sport, Health \\ and recreation Faculty of Sport Science \\ Semarang State Universityn) \\ Semarang, Indonesia \\ wahyu_zabidin@unnes.ac.id
}

\begin{abstract}
Smash Kedeng is important to get points in Takraw's game, but it's very difficult to do. Therefore, it is necessary to develop appropriate training. This study aims to examine the right exercise to improve smash Kedeng ability. This experimental research used sample of 20 male athletes using two independent variables: plyometric tuck jump and lateral hurdle jumps, and one dependent variable: ability of Smash Kedeng. Data were analyzed with t-test. The result was lateral plyometric exercises hurdle jumps are better than tuck jump exercises for the ability to smash Kedeng.
\end{abstract}

Keywords - Plyometric, Tuck Jump, Lateral Hurdle Jumps, Smash Kedeng Introduction

\section{INTRODUCTION}

Takraw is a game that uses the skill of the foot to play the ball. This game is performed by two squads on the field as wide as a badminton court. Each team consists of three players. In order to play sepak takraw, one is required to have basic skills or skills consisting of kicking with the legs, playing the ball with the head, with the thighs, shoulders and soles of the feet. Mastery of sepak takraw skills can be individual skills, and matching skills[1]. Individual skills include: sepak sila, sepak kura, sepak badek, sepak cungkil, memaha (thigh control), mendada (chest control), and heading, while the skills to master the game include: sepak mula (service), receiving the ball, feeding, smash and block. Smash in takraw is a special technique that must be controlled by all players, especially the players in the position apit kanan and apit kiri. Smash in takraw has a higher difficulty level compared to other techniques. Smash is one of the most important attack techniques and is a very decisive series of motion in the game sepak takraw (Winarno, 2011, p. 6)[2].

Smash kedeng is a smash done with the feet. The players, apit kiri and apit kanan have many opportunities to do smash kedeng. For that, to have an ability to attack the opponent team, players need to have a good smash ability (Darwis \& Basa, 1992, p. 69)[3]. Sometimes a player jumps ahead of the ball, so when the ball blow has not reached within the range or the ball has dropped first, so the player fails to smash the ball or ball stuck on the net.

Smashes require physical abilities including: speed, agility, strength, thunder, leap and foot blow on the ball to do smash. To produce the maximum smash, it need appropriate method to increase the precision and accuracy. In other words the right method could improve the ability of smash on takraw's athletes (Annas, 2014)[4].

Speed will affect the movement of smash kedeng, because this physical ability is an important for athletes. Smash can be done with the shortest time possible. To do smash kedeng, the athlete must also have the Power. Power is the result of multiplication between strength and speed. To increase the power of the athlete it takes strength and speed training (Sukadiyanto, 2011)[5]. It's an ability to move the body and its parts without feeling the tension on the articulations and muscle pairs. Athletes who have a good level of flexibility will be able to smash kedeng perfectly. In addition to the flexibility, the balance is necessary to do smash kedeng, especially to maintain posture when doing smash kedeng. If the balance is good, the player wouldn't fall easily when doing the movement of smash kedeng during the game.

Plyometric is an exercise or repetition aimed at connecting the movement of speed and power to produce explosive movements. Plyometric exercise can result in strong muscle contraction with very rapid movement (Chu, 1991, p. 1)[6]. Plyometric is a form of training to achieve explosive power for all sports activities. Explosive power is the power of the muscle movements performed at high speed (Bompa, 1994). Plyometric is associated with exercises that are strong and rapid muscle contractions in response to the speed of dynamic changes and stretching of the muscles involved. The plyometric exercises in question are barrier hops, depth jump, multiple box-to-box jumps, stadium hops, single leg stride jump, skipping, tuck jump and lateral hurdle jumps ${ }^{7}$. These types of exercises can improve the speed, agility, balance, 
power and flexibility of a player when done in earnest and progressively practiced progressively.

Tuck jump exercises and lateral hurdle jumps, a form of training that will be given to the male athlete Takraw to increase muscle limb power in the athlete while performing smash ability kedeng. Both of these exercises using leap leg strength, but in the form of exercise tuck jump leap and lateral hurdle jumps are different. Each of both exercises, has advantages and disadvantages, but it is not known which exercise has a great impact on improving the ability of smash kedeng at male athlete takraw at Club Padang Jagad. Not all athletes have good physical ability in doing smash kedeng. Only a small number of takraw's male athlete in Club Padang Jagad having the ability to do a good smash kedeng. Therefore, it is necessary to examine what factors influence the achievement of male athlete takraw Club Padang Jagad either from coaching, implementation of practice, methods applied and otherwise.

Based on the problems that have been stated, takraw's male athletes at Club Padang Jagad still have weaknesses in the physical ability of both the leap, impact, speed, flexibility and balance when performing smash ability so that smash punch produced is not maximal. The purpose of this study were: 1) to analyze the effects of exercise plyometrics tuck jump on ability of smash kedeng on takraw's male athletes, 2) to analyze the effects of exercise plyometrics lateral hurdle jumps on ability of smash kedeng on takraw's male athletes, and 3) to analyze the exercise appropriate between plyometric tuck jump and lateral hurdle jumps on the smash ability of takraw's male athletes.

\section{MATERIALS AND METHODS}

This research use experimental research method with design Matched by Subject Design. The population in the study were 26 takraw's male athletes at Padang Jagad Club of Demak Regency in 2017. Samples used are 20 athletes, using a purposive sampling technique, male athletes who have good mastery of smash techniques. The sample was tested with vertical jump test, then divided into 2 groups with the same ability using matched subject ordinal pairing technique, with the aim of balancing the two groups before doing the treatment in research using ABBA formula. The sample was divided into 2 groups of Experiment 1 and Experiment Group 2, Experiment Group 1 group was given plyometric tuck jump training and Experiment 2 group was given lateral hurdle jumps practice. The research instrument used there are 2 kinds, namely 1) Test vertical jump and 2) Test of Kedeng smash ability. The exercise was done in 14 times with the training program that has been made adapted to the ability of athletes. Afterwards, do the final test with the test of Kedeng smash ability, 10 time. The data of the research were analyzed using t-test statistic to know the effect of the difference.

\section{RESULT AND DISCUSSION}

Plyometric exercises in some studies show their effectiveness to improve agility, muscle formation and strength or power. Plyometric training has evolved into a widely accepted and greatly effective tool to improve power and agility. Athletes of all ages and skill levels can safely perform plyometric exercises[7]. Plyometric training can be an effective training technique to improve an athlete's agility[8]. Plyometric can improve the production of muscle force and power. In particular, the fast force production of the trained muscle improves, coupled with smaller increases in maximum isometric force[9]. Pyometric training used in this researh was tuck jum and lateral hurdle jumps.

The results of the analysis of research data are presented in Table 1, which can be described as follows:

TABLE 1. DESCRIPTION OF RESEARCH DATA

\begin{tabular}{cccccc}
\hline & $\mathrm{N}$ & Mean & Min & Max & $\begin{array}{c}\text { Std. } \\
\text { Dev }\end{array}$ \\
\hline $\begin{array}{c}\text { Pre-test } \\
\text { Vertical }\end{array}$ & 20 & 49.00 & 40 & 62 & 6.83 \\
$\begin{array}{c}\text { Jumps } \\
\text { Pre-test Tuck } \\
\text { Jump group } \\
\quad \text { Pre-test }\end{array}$ & 10 & 14.80 & 11 & 20 & 3.28 \\
$\begin{array}{c}\text { lateral hurdle } \\
\text { jumps group }\end{array}$ & 10 & 16.40 & 12 & 21 & 3.46 \\
$\begin{array}{c}\text { Post-test Tuck } \\
\text { Jump group } \\
\text { Post-test }\end{array}$ & 10 & 18.00 & 15 & 23 & 2.86 \\
$\begin{array}{c}\text { lateral hurdle } \\
\text { jumps }\end{array}$ & 10 & 20.90 & 16 & 26 & 3.47 \\
\hline
\end{tabular}

Based on the result with t-test, experimental group 1 (tuck jump) showed that pretest and posttest were 8.500. Test of significance (t-test) is done with significant level at $\alpha=5 \%$ with $\mathrm{db}=10-1=9$. $\mathrm{T}$ count is bigger than $\mathrm{t}$ table with 8.500> 2.262 , it means that alternative hypothesis (Ha) is accepted. These results indicate that there is a significant influence from the results of tuck jump plyometric training on smash kedeng ability's at takraw's male athletes in Club Padang Jagad, Demak regency in 2017.

The pretest and posttest data of experimental group 2 (lateral hurdle jumps) was analyzed to determine if there was any difference of effect of athlete smash ability's at Club Padang Jagad Demak Regency in 2017 before and after the lateral plyometric hurdle jumps.

Based on the test results of the influence with t-test statistical analysis, in the experimental group 2 (lateral hurdle jumps) it is known that the pretest and posttest results obtained value of 13.636. Test of significance (t-test) shows that $t$ count $>\mathrm{t}$ table with significant level at $\alpha=5 \%$ with $\mathrm{db} .=10$ $1=9$, shows that $t$ count is bigger than $t$ table 13.636>2.262. It means that the alternative hypothesis ( $\mathrm{Ha})$ is accepted. These results indicate that there is a significant effect of the lateral plyometric hurdle jumps on the ability of smash kedeng at takraw's male athlete at Club Padang Jagad Demak Regency in 2017.

The effect of posttest result data on experimental group 1 (tuck jump) and experimental group 2 (lateral hurdle jumps) was done to determine if there is difference of effect of smash 
kedeng ability's on athlete of takraw at Club Padang Jagad in Demak Regency in 2017 after doing plyometric training tuck jump and lateral hurdle jumps. The result of calculation of influence test using t-test is presented in the following table.

Based on test result of influence with t-test, posttest result in experiment group 1 (tuck jump) and experiment 2 group (lateral hurdle jumps) obtained value 2.230. Test of significance (t-test) is $t$ count $>t$ table with significant level at $\alpha=5 \%$ with $\mathrm{db}=10-1=9$. T count is bigger than t table: $2.230>2.262$. It means that the null hypothesis (Ho) is accepted. These results indicate that there is no significant effect of tuck jump and lateral hurdle jumps on the ability of takraw's male athlete to do smash kedeng.

To know which experimental group has an improved percentage of smash capability that can better be known through calculation of the effect of percentage improvement of each group. The results of the value of the effect of enhancing the ability of smash kedeng in percent between the experimental group 1 (tuck jump) and the experimental group 2 (lateral hurdle jumps) as follows:

TABLE 2. PRE-TEST, POST-TEST AND INCREASEMENT

\begin{tabular}{cccccc}
\hline & $\mathrm{N}$ & $\begin{array}{c}\text { Mean } \\
\text { pretest }\end{array}$ & $\begin{array}{c}\text { Mean } \\
\text { posttest }\end{array}$ & $\begin{array}{c}\text { Mean } \\
\text { Different }\end{array}$ & $\begin{array}{c}\% \\
\text { Increasement }\end{array}$ \\
\hline $\begin{array}{c}\text { Experiment } \\
\text { group 1 }\end{array}$ & 10 & 14.80 & 18.00 & 3.20 & $21,62 \%$ \\
$\begin{array}{c}\text { Experiment } \\
\text { group 2 }\end{array}$ & 10 & 16.40 & 20.90 & 4.50 & $27.42 \%$ \\
\hline
\end{tabular}

Based on calculation result of percentage of smash upgrading, it is known that experiment 1 group (tuck jump) has an increase of smash ability of $21,62 \%$, while experiment 2 group (lateral hurdle jumps) has $27,42 \%$ improvement of smash kepeng capability. It means that the alternative hypothesis (Ha) is accepted. Based on these results, the experimental group 2 (lateral hurdle jumps) has improved the ability of smash kedeng better than the experimental group 1 (tuck jump) with a percentage increase of $27.42 \%$.

The results showed that there is influence between tuck jump exercice on the ability of smash kedeng in takraw. Tuck jump is a practice of jumping motion with the knees bent and the foot refusing on the ground to jump and land with a shovel. The plyometric tuck jump exercises will affect the gluteus, gastrocnemius, quadriceps, hamstring, and hip flexors[10]. Similar research shows that the practice of using plyometric jump to box increased on average 1.361 was better than using a double tuck jump plyometric exercise with an average increase of 1,210[11].Tuck jump training exercises hamstring muscle strength because at the time of jumping and the knees bent, hamstring muscle is very dominant in the movement of the lower leg, especially on the back. When performing a leap, hamstring muscle plays an important role to provide power the muscle contraction in a concentric and extrinsic to the maximum with the practice of tuck jump. In addition to the practice of smash kedeng also done to improve the ability of athletes through plyometric training tuck jump both in terms of the speed of discharge and the accuracy of the punch when hitting the ball in the air.

The plyometric exercise can increase leg muscle power by $23 \%$ (Suratmin, I Putu Panca Adi, 2016)[12]. An other research mentioned also that there is a difference in the effect between having a high and low limb muscle explosive power to a high limb muscle explosive outcome having greater influence compared to low limb muscle explosiveness in jump results[13].

The results showed that there is influence between lateral hurdle jumps practice on the ability of smash kedeng on athletes takraw. Lateral hurdle jumps are the same exercises as a tuck jump with a jumping motion with the knees bent and the foot refusing on the ground to jump and landing with a shovel, but the leaping direction of this exercise to the side by passing the hurdles as a 45 centimeter high hurdle. Lateral hurdle jumps exercises press on the balance, strength, and speed of leg movement to achieve the highest jump and jump as far as the side. When doing a smash kedeng required balance and speed to jump for smash kedeng can be done well when the ball is fed to the side of a smasher. This is because the lateral plyometric exercise hurdle jumps can improve the ability of the athlete in terms of balance, strength and speed leap to the side. With the ball bait being thrown to the side, the athlete can perform a maximum smash with the maximum and aim the ball into the field.

The result of this research mentioned that there is influence between tuck jump and lateral hurdle jumps on the ability of smash kedeng at takraw's males athletes at Padang Jagad Club of Demak Regency in 2017. Tuck jump and lateral hurdle jumps training on the ability of smash kedeng is $(21.62<27.42)$ then it can be concluded "lateral plyometric practice hurdle jumps are better than plyometric tuck jump exercises. This is because the lateral plyometric practice of hurdle jumps has the advantage of a sideways leaping motion that resembles a smash-like motion. This exercise emphasizes the balance, strength and speed of the leap to the side. This exercise train athletes to do smash kedeng by directing the target ball to the field area.

\section{CONCLUSION}

Based on the results of research and discussion in this study it can be concluded that there is an influence between tuck jump exercise on the ability of smash kedeng at takraw's athletes, there is an influence between the lateral practice hurdle jumps on the ability of smash kedeng, and lateral plyometric hurdle jumps is better than the tuck jump plyometric on the ability of smash kedeng. From these conclusions can be suggested for trainers or coaches are advised to use lateral training methods hurdle jumps as an alternative exercise to improve the ability of smash kedeng.

\section{REFERENCES}

[1] Sulaiman. (2008). Sepak Takraw, a Sport Teacher guidelines for Builders, coaches and Athletes. Semarang: Universitas Negeri Semarang. 
[2] Winarno. (2011). The influence of Kelentukan exercise and Methods Against the results Smash Kedeng Sepak Takraw players Junior Prince of the universe in the Paddock Club demak Year 2011. Unpublished

[3] Darwis, R., \& Basa, P. (1992). Sepak Takraw Sport Of Choice. Jakarta: Depdikbud.

[4] Annas, M. (2014). The influence of the Exercises Area Using Gradual Kedeng Smash against the Smash Skill Sepak takraw. Journal of Physical Education, Health and Sport. Vol 1

[5] Sukadiyanto. (2011). Introduction to the theory and methodology of Physical Exercising. Bandung: CV Lubuk Agung.

[6] Chu, D. (1991). Jumping into plyometrics. Champaign: IL: Leisure Press.

[7] Matthew R.Kutz,MS,MEd,CSCS.2013.Theoretical and Practical Issues for Plyometric Training. NSCA's Performance Training Journal Volume 2 No. 2

[8] Michael G. Miller, Jeremy J. Herniman, Mark D. Ricard Christopher C. Cheatham and Timothy J. Michael.2006. "The Effects Of A 6-Week Plyometric Training Program On Agility”. Journal of Sports Science and Medicine (2006) 5, 459-465
[9] Kevin Thomas, Duncan French, and Philip R. Hayes.2009. “The Effect of Two Plyometric Training Techniques on Muscular Power and Agility in Youth Soccer Players".Journal of Strength and Conditioning Research

[10] Radcliffe, J. F. (2002). Plyometrics Explosive Power Training. Ilinois: Human Kinetics Published, Inc.

[11] Ikhvanus Sava, Donny Wira Yudha, Tri Rustiadi. 2017. Plyometrics exercises and long Limbs against the speed of Swimming Breaststroke Swimming athletes of South Sumatra. Journal Physical Education and Sport. Vol. 6 No. 3

[12] Suratmin, I Putu Panca Adi. 2016. The Application Of Pliometrik Training Methods In Improving Power Limb Muscles Jocks PPLM Bali. Journal Physical Education.Health and Sport. Volume 3 No. 1

[13] Abdulloh Faqihudin, Moh. Nasution, Wahadi. 2015. Influence Yield and long Limbs against the results Jump Heading on the player's football Practice the centrality of Kendal. Journal of Sports Science. Vol.4 No. 2 